\title{
From Alms to Arms: The Almajiri Phenomenon and Internal Security in Northern Nigeria
}

\author{
Iro Aghedo* and Surulola James Eke**
}

\begin{abstract}
State and multinational efforts aimed at containing jihadist terrorism in northern Nigeria have only yielded modest results despite the repressive nature of these efforts. The ranks of the foot soldiers of Boko Haram and Ansaru fundamentalist Islamic sects continue to swell even in the face of the ferocious onslaught on their membership by state troops. In contrast to mainstream analyses that highlight the salience of radical Islamism in coming to terms with insurgent proliferation, this article demonstrates that jihadist insurgency in northern Nigeria is better understood as a consequence of youth bulge syndrome, particularly the low-cost availability of foot soldiers from the almajiri demographic cohort. Abandoned by parents and the state, the itinerant Quranic pupils resort to street, begging for alms and survival. And "street life" exposes the urchins to abuse, criminalization and subsequent mobilization for violent causes including terrorism. It is argued that until the practices of rampant child abuse and state neglect of the almajirai and other vulnerable groups are addressed through better education, employment opportunities and poverty reduction, northern Nigeria is likely to remain a breeding ground of violent conflicts.
\end{abstract}

Keywords: Nigeria, youth bulge, Boko Haram, almajiri, terrorism

* Iro Aghedo (corresponding author) is a lecturer in the Department of Political Science, University of Benin, Benin City, Nigeria. He was educated at the universities of Ibadan and Benin in Nigeria and at the College of North-west London and the School of Oriental and African Studies, University of London. He specializes in comparative and environmental politics, and strategic and security studies. His articles have been published in both national and foreign journals. E-mail: iroaghedo@yahoo.com.

** Surulola James Eke is a lecturer in the Department of Political Science, University of Benin, Benin City, Nigeria. He took degrees in political science at the University of Benin and the Obafemi Awolowo University, Ile-Ife. His articles have been published in both national and foreign journals, including African Security Review. Email: lolaeke@yahoo.co.uk.

Manuscript received July 18, 2013; out for review August 15, 2013; review completed December 16, 2013; accepted December 18, 2013.

The Korean Journal of Policy Studies, Vol. 28, No. 3 (2013), pp. 97-123.

(C) 2013 by the GSPA, Seoul National University 


\section{INTRODUCTION}

Insurgent activities have surged across Nigeria since the country returned to civilian rule in 1999 after over 16 years of continuous military dictatorship. From the Niger Delta in the South through the North-central region to the hardcore North, violent conflicts have been a hallmark of social life in Africa's most populous and largest oilproducing nation. The Boko Haram $(\mathrm{BH})$ uprising is the deadliest conflict yet since the 1967-1970 Nigerian Civil War that claimed over a million lives. The BH, which formed in 2009 in northern Nigeria, was rated in 2012 as the second deadliest terror group in the world, having killed a total of 1,132 persons in 364 attacks, only surpassed by Afghanistan's Taliban, which killed 1,842 persons in 525 attacks (Guardian, 2013a; Egharevba \& Aghedo, 2013). According to a recent study conducted for the American government by the University of Maryland on global terrorism, such BHrelated deaths exceeded those inflicted by Al-Qaeda in Iraq, the Maoists in India, and Al-Shabaab and Al-Qaeda in the Arabian Peninsula. Employing strategies such as assassination, arson, jail breaks, terrorist kidnapping, and suicide bombing among others, the Islamic fundamentalist group targets security formations, government institutions, authority figures, churches, schools, media and Western interests with the ultimate motive of establishing an Islamic republic to replace the secular state in Nigeria (Osumah, 2013; LeVan, 2013).

The Nigerian state has relied heavily on repressive instrumentalities in managing $\mathrm{BH}$ violence (including arrest, detention, proscription of the group, declaration of emergency rule in parts of the North, and killing of the sect's members) despite the fact that some perceptive observers and analysts of the region argue for conciliatory measures, including poverty alleviation, mass literacy promotion, dialogue, and amnesty with pay (this last being the approach the government adopted in the case of the oil-producing Niger Delta region of the country; see Aghedo, 2013). Even though the state has mooted the idea of a possible dialogue and amnesty, its security management strategy has been ostensibly brutal, perhaps in line with the "war on terror" doctrine that the United States and its allies have articulated in response to transnational terrorism. Indeed, on November 13, 2013, the United States formally designated BH and Ansaru as foreign terrorist organizations and as specially designated global terrorists after initially offering a $\$ 7$ million reward for information leading to the capture of $\mathrm{BH}$ leader, Abubakar Shekau (Campbell, 2013).

Despite repressive counterterrorist tactics, the $\mathrm{BH}$ membership has become more radicalized and continues to swell, much to the consternation of the Nigerian state and its foreign sympathizers. Most analysts blame terrorism escalation on militant Salafism (Agbiboa, 2013; Alao, 2013; Winters, 1987). In contrast, we contend in this article that 
$\mathrm{BH}$ proliferation and escalation are better understood as a consequence of a "youth bulge" syndrome, especially the availability of "cheap" foot soldiers from among the almajirai (singular almajiri). These itinerant Quranic pupils, we argue, do not only constitute the largest number of out-of-school children in the country and a tremedous challenge to the realization of both national and international conventions and protocols related to children, including education for all objectives and the millennium development goals, but also pose a direct threat to national security. Yet security scholars and analysts have not significantly explored the almajiri phenomenon. We attempt to fill this research fissure by revealing how parental child abuse and state neglect fuel insecurity in northern Nigeria with the consequence that many almajirai have foregone begging for alms and taken up arms instead.

The menace of street children, it must be noted, is not peculiar to northern Nigeria, as evidenced by the hooliganism of "area boys" (a generic term for mostly male delinquent youths) in many southwestern cities of Nigeria, especially Lagos (Olley, 2006; Momoh, 2000). And there are a few almajirai in other West African states with sizable Muslim populations, such as Niger, Mali, Senegal, and Burkina Faso. Moreover, the youth crisis in other parts of Africa, especially the predicament and dangers of street urchins in such countries as Sierra Leone, Liberia and South Africa (Kaplan, 2006; Vigh, 2006; Abdullah, 1997), has been critically interrogated. For example, O'Brien (1996) locates the root cause of youth crisis in poor governance and obnoxious economic policies such as the structural adjustment program of the mid-1980s, which have made the hope of the youth unrealizable. Similarly, Gore and Pratten (2003) and Diouf (2003) argue that because many hopeless young Africans now operate from a marginal geography and culture that is largely oppositional and antagonistic to the dominant culture, their engagement with the state has become ambivalent, characterized by complicity, insurgency, and disengagement. This alienation in turn pushes the youth resorting to embrace alternative survival strategies outside mainstream and socially approved means of livelihood, which exposes the entire society to instability. Other scholars blame the crisis on the ambivalent character of African elites, who often violently mobilize vulnerable youth in their overweaning struggle for power and resources. Many young people are now seen as an "expendable category" and a "war machine" in much of Africa today (Maclay \& Ozerdem, 2010; Chabal, 2005; Lewis, 2004; Ukiwo, 2002).

A number of scholars locate the rootedness of youth crisis in the African colonial situation, although they agree that postcolonial misgovernance has compounded the problem. In colonial Africa, as Richard remarks, "the disruptive and unequal opportunities of social and economic change and the realities of racial domination were apparently creating juvenile delinquents, not junior citizens, and encouraging 
new forms of unruliness and defiance" (2006, p. 79). Similarly, obnoxious colonial policies had led to the emergence of "Jaguda Boys" in Nigeria for whom petty crime was a matter of survival, and in certain situations violence might be functional for the young. Today, the growing incapacity of many states to ensure good governance and human security has exacerbated the crisis of African youth, who have become, as Osaghae rightly notes, "a social category in crisis, being excluded, marginalised, threatened, victimised, abused, and consequently angry, bitter, frustrated, desperate and violent" (2007, p 7). But crucially, even advanced societies such as the United States and United Kingdom are also not immune from youth crisis, as exemplified by sporadic shooting sprees at cinemas, on campuses and in the streets by gun-trotting young men (Foley, 2009). However, the African youth experience is dire, which is even more disheartening given that at independence in the 1960s, the youth were conceived as the hope of the continent. The almajiri phenomenon in northern Nigeria clearly showcases the descent and overwhelmimg crisis of the African youth.

To set the tone for the discourse, the following questions suffice: What is the relationship between $\mathrm{BH}$ and the almajirai? And how can we make sense of almajiri-related insecurity? In proferring answers to these questions, we argue that the BH Islamic fundamentalist sect draws a substantial number of its foot soldiers from the almajiri demographic cohort. Thus, addressing the driver of $\mathrm{BH}$ terrorism requires an approach that tackles the root causes of the almajiri problem; and an understanding of the causes may contribute to finding a way to deny BH easy access to its "war machine." This interrogation of terrorist recruitment strategy is therefore novel and provides some insights into how best to respond and mitigate the scourge of terrorism in Nigeria. The article is structured into six parts. Following this introduction is the second segment which examines the analytical utility of the concept of "youth bulge." The third slice examines the origin and dynamics of the almajiri phenomenon. The fourth part considers the security implications of the almajirai. The fifth portion addresses the drivers of the almajiri syndrome. The sixth and final section offers a number of policy prescriptions.

\section{THEORIZING YOUTH BULGE}

We situate the almajiri phenomenon and its attendant insecurity within the context of "youth bulge." There is no universally agreed-on definition of the term "youth". However, the concept is often used to describe the age bracket between 15 and 24, though the upper age range could be as high as 35 in many African countries and the lower range as low as 12 in others, such as Jordan (Hilker \& Fraster, 2009). Also, 
there can be a high degree of overlap between the definitions of "youth" and "children." For example, the Convention on the Rights of the Child defines "child" as anyone under the age of 18 years. In essence, youth "is better understood as a transitional stage in life between childhood and adulthood rather than as a rigid construct based on age" (Hilker \& Traser, 2009, p. 9).

The term "youth bulge" was coined by German social scientist Gunnar Heinsohn and popularized in the 1990s by American political scientists Gary Fuller and Jack Goldstone (Hoffman \& Jamal, 2012; LaGraffe, 2012). Proponents of the theory argue that "societies characterized by a youth bulge (a burgeoning youth population) while simultaneously facing limited resources and, in particular, a lack of prestigious positions for 'surplus' youngsters - i.e. the third, fourth, fifth etc. born children-are much more prone to social unrest and acting belligerent towards their neighbours than those societies without these demographic stressors" (Schomaker, 2013, p. 117). The theoretical foundation of the youth bulge is based on the premise that countries with weak political institutions that are undergoing demographic transitions are vulnerable to social unrest, rebellion, and violent conflicts because of the likelihood that the unemployed male youth will seek socioeconomic advancement through extralegal means. Societies that fit the youth bulge profile are mostly prevalent in sub-Saharan Africa, Asia, the Middle East, and the Pacific Islands and usually have a large youth cohort (over 30 percent) relative to the adult populations (Schomaker, 2013; Hart, Atkins, Markey, \& Youniss, 2004).

Though the youth bulge theory gained much prominence in social science circles only in the 1990s, the historical data suggests that youth cohorts have longed played a critical role in conflicts. For example, a youth-bulge syndrome was evident in Russia between 1897 and just before the young Bolsheviks staged the 1917 Revolution. Similarly, historical studies have implicated youth bulges in revolutions in 17th-century England, 18th-century France, and 20th- century Indonesia, France, and Iran (Goldstone, 2002; Moller, 1968). More recent researches have linked youth bulges to political activism, warfare, and terrorist uprisings, especially in the Arab world (Hoffman \&Jamal, 2012; Huntington, 1996). The Arab Spring and the Islamic revivalism that swept across countries such as Tunisia, Algeria, Libya, Egypt, and others are further manifestations of the growing link between demography and security. The theory has been influential in shaping U.S. foreign policy; indeed, some of the advocates of youth bulge such as Fuller and Goldstone have been appointed as advisors in key U.S. government agencies, including the CIA (Schomaker, 2013).

However, the intersection between youth bulge and violence is not automatic. There are a number of variables that intervene between demography and security. Some of the conditions that exacerbate the youth bulge phenomenon include unemployment, 
relative poverty, and urbanization. Members of the youth demographic cohort find it difficult to translate their education into sustainable jobs in fragile states, leading them into poverty. As noted by LaGraffe (2012, p. 67), demography acts as a "force multiplier," aggravating these preexisting conditions. The alienation, frustration, and growing discontent arising from lack of sustainable livelihoods, along with other stressors, make the youth easily susceptible to mobilization for violence. The volatility of a ballooning youth population, especially of youths between ages 15-24, is further propelled by the lack of developmental maturity on the part of the so-called "surplus sons". Added to these intervening variables is being unmarried, which means the young men tend to have time for risky engagements, including participation in rebellion that are known to have a low opportunity costs. Thus, angry male youths are allegedly "driven to violence by their very biology" (Corner House, 2004, p.10).

The theory of youth bulge is particularly suitable in relation to Africa because of the unemployment and poverty profile of the continent and the fact that the youth constitute more than 35 percent of the population. The population of people under 14 years is even over 44 percent in such countries as Sierra Leone (Bricker \& Foley, 2013; Mkandawire, 2002; Kaplan, 1994). The lack of "access to power, position and other resources by the youth greatly reduces their space of possibilities," which is often interpreted as "social death" (Vigh 2006, p. 37). A burgeoning African youth population coexists with "soaring unemployment, endemic poverty, and failing schools" (Potts \& Campbell, 2009, quoted in Kegley \& Blanton, 2011, p.490). Indeed, Kaplan (2006) paints a tapestry of horror of African youth and the volatile environment they inhabit because of their constricted options. The crisis of the African state compounds the phenomenon of youth bulge, driving young Africans to seek escape from "confining structures and navigate economic, social and political turmoil" (Christiansen, Utas, and Vigh, 2006, p. 9). This disenchantment has been further accentuated by a pervasive negative culture which Abdullah (1997) called "lumpen youth." This street-based culture positions the youth against mainstream culture with attendant negative consequences.

Despite its popularity, youth bulge theory has been criticized for being a tool for the promotion of American interests. It has been alleged that the "demographic time bomb associated with a youth bulge is a myth used by the US to justify its military intervention and population control efforts in the South" (Corner House, 2004, p. 2). The criticism has been further buttressed by the fact that youth bulge theory was originally aimed at providing US intelligence with a tool by which to uncover national security threats, coupled with the fact that a large youth population could be a blessing rather than a curse, as exemplified by the Asian Tigers (Corner House, 2004). Notwithstanding these criticisms, the theory makes intuitive sense. A surge in youth 
population means an increase in the demand for jobs and other sociopolitical goods. In weak societies that are characterized by corruption, poor governance, ineffective public institutions, and an attendant high rate of unemployment and poverty, the youth often use their energy and vigor for antisocial and violent purposes.

\section{THE ALMAJIRI PHENOMENON: ORIGIN, AIMS AND DYNAMICS}

The almajiri practice is an old tradition that remains attractive to certain segments of the population. The word "almajiri" is an adulterated spelling of the Arabic word "almuhajir," which refers to a person who migrates for the purpose of learning or for the sake of propagating Islamic knowledge. Every year, usually after harvest, people inhabiting a particular neighborhood would gather their children, mostly school-age males (from age six upward), and hand them to an Islamic scholar (mallam). The mallam's purpose was to teach the children the basics of Islam and how to write and recite the Arabic alphabet (Oladosu, 2012). In order to escape the distractions of life, the mallam would take the almajirai out of the city to a camp where they were taught self-reliance as well as discipline. Sometimes, when there was shortage of food, the Quranic teacher would send the pupils out to solicit for food from residents around and the food would be brought back to the camp for all to eat. This practice of soliciting for food by the almajirai became known as "almajiranchi"- - a practice meant to make them strong and to prepare them for life's struggle.

In fact, the almajiri system produced eminent jurists, Islamic scholars and religious reformers in the past, when their numbers remained within manageable limits. Since the 11th century, Quranic teaching has been a medium of Islamic education in the country. The population of Nigeria is about 50.4 percent Muslim, 48.2 percent Christian, and 1.3 percent adherents of other faiths (Kew and Lewis, 2013). Currently, Nigeria has a 9-3-4 system of formal education: compulsory basic schooling takes nine years, senior secondary schooling takes three years, and most courses in the university except engineering, law, and medicine run for four years. In addition to this, a nonformal system of education is operational among Muslims and includes the Quranic, Islamiyyah, and almajiri schools (Oladosu, 2012).

As far back as 1921, there were 30,411 Islamic schools in northern Nigeria, and by 2006, it was estimated that over seven million males a year were matriculating into Quranic schools (Aluaigba 2009:20). Currently, there are about 9.5 million almajirai in northern Nigeria (Oladosu, 2012). About half of these are domiciled in the core Northeast geographical zone, which is also the hotbed of BH terrorism. The high rate of enrollment into almajiri schools all over northern Nigeria contrasts sharply with the 
low enrollment in formal schools and represents a serious problem. A 2009 survey carried out by the National Primary Education Commission (NPEC) indicated that the enrollment of pupils into Quranic schools trippled that of formal schools in Sokoto and Zamfara states. A similar trend was observed in a survey conducted by the Federal Ministry of Education and UNICEF in 2008, which revealed a total pupil enrollment of 514, 264 in Bauchi, Borno, Kano, Katsina, Sokoto, and Zamfara states. When these figures are compared with the total number of 54,434 public primary schools across the country, it becomes clear that Quranic schools have a commanding presence in the North (Olagunju, 2012).

The scope of curriculum in Quranic schools is myopic, as it does not include such orthodox subjects as mathematics, English, social studies, and basic science. The almajiri curriculum centers mainly on the reading and the writing of the Quran and on tafsir, hadith, and tawhid and other branches of Islamic studies (Oladosu, 2012, p. 1821). This deficiency in science-oriented subjects and in modern information, communication, and technology, as well as entrepreneurial skills development, negatively affects the students in the labor market after graduation, making many of them unemployable. Perhaps it is because it has become an avenue for imbuing the youth with skills that are not needed in the labor market that many people have concluded that almajiri culture has outlived its importance. Indeed, the almajiri population has grown exponentially, and a large majority have been unable to turn their education into productive jobs, thereby turning them into "social misfits" who pose a security risk (Aluaigba, 2009).

With time, the almajiri system, which was meant to inculcate Islamic virtues in the youth, degenerated into a practice characterized by unwholesome and inhumane activities. At the formative stage of almajiri schooling, it was not envisaged that the Quranic pupils would have to beg for alms permanently or do menial jobs for their survival, as it is the practice today. These days, a typical almajiri can be spotted by his unsavory appearance - dressed in tattered clothes, disease afflicted, and armed with a plastic plate, he roams the streets begging for alms. Socially regarded as nuisance, the almajirai are often chased away by decent people. They hang around restaurants, markets, shops, petrol stations, and houses, most times sleeping on disused pieces of cardboard or bare floors. The street urchins bemoan their fate as they watch other privileged children enjoy life with their parents (Olagunju, 2012; Loimeier, 2012). As a result of these social and economic deprivations, some almajirai end up becoming commercial errand boys, hewers of wood, or fetchers of water (known locally as "mai rua"). Yet many take to petty theft, thuggery, and peddling of hard drugs. Some find life too cruel and unbearable to be meaningful and commit suicide. This was the case with a young almajiri who hanged himself at the Ungwar Maihauta area of Minna in 
Niger state in 2011 (Adofetekun, 2011).

The socioeconomic destitution of the almajirai makes them easy prey to conflict enterpreneurs-desperate politicians who will stop at nothing in their quest for power and resources - who pay the street urchins peanuts to execute criminal acts. Today, the almajirai have become ready-made recruits for prosecuting violence against political and business opponents and rivals. As rightly noted by Oladosu, many almajirai are:

Exploited and used by the politicians as thugs and hoodlums to foment trouble, cause a riot, disrupt peace and achieve selfish political interest. In fact, it has been alleged that most of the terrorist attacks involving suicide bombings, setting places of worship ablaze, killing innocent souls and destroying property were masterminded by jobless pupils of the Al-majiri schools (Oladosu, 2012, p. 1821).

The instrumentalization of disaffected youth for violence is, however, not new in the region. Militia groups such as Dan Kalare in Gombe, Yan Sara Suka in Bauchi, ECOMOG in Borno were, for instance, used by politicians in their struggle for power in the run up to the 2007 elections and thereafter (Human Rights Watch, 2011). In addition to these groups and the more notorious Hisba, there are a plethora of local gangs such as Yan Farauta (gangs of hunters), Yan Tauri (persons who make and use ritual herbal medicine to prevent injuries from weapons), and Yan Dada (young marginal toughs) who lead violent lives on the edges of urban society in northern Nigeria. The ready availability of the members of these groups has been accompanied by the growing dysfunctionality and corruption of the federalized police force, creating a serious problem (Last, 2008; Dawha, 1996).

The almajirai are even abused by the mallams, who are supposed to stand in loco parentis to them. It is usually a tall order to bring back the proceeds they get from the sorts of dehumanizing jobs they do. Recently, a ritualist mallam was caught sucking the penis of an almajiri. The mallam confessed that the sperms were to be used for money rituals (Oladipo, 2012). However, though the almajirai are more vulnerable to abuse than other children, the menace of child abuse is national in Nigeria. Children are conscripted for street hawking, domestic service, and commercial sexual exploitation as well as for dangerous artisanal gold mining. And in addition to domestic trafficking in persons (including children and youth), the country is notorious for being a source, transit point, and destination of international human trafficking (Aluaigba, 2009). 


\section{THE SECURITY IMPLICATIONS OF ALMAJIRI (AB)USES}

The abuse of the almajiri has a number of implications for state and society in Nigeria as well as for the country's immedite neighbors. As noted earlier, the abuse of the children makes them extremely vulnerable to conflict entrepreneurs-especially do-or-die politicians-desperate business persons, and clerics preaching religious intolerance (Imobighe, 2012) who promise better life opportunities. The system has over time become a breeding ground for criminality and insecurity (Loimeier, 2012), spawning youths who are significantly inclined to violence as a means of survival or making their voices heard. Almajiri training provides one of the easiest avenues for indoctrination and radicalization. For example, the almajirai are made to chant songs of protest and radicalization that criticize "makarantan boko" (schools providing western education) and praise "makarantan addini or makarantan allo" (schools for Islamic instruction):

Yan makarantan boko

Ba karatu, ba sallah

Sai yawan zagin mallam

The song translates as:

Pupils of Western schools,

You do not learn or pray

but only abuse your teacher.

Indeed, the case of almajiri Usman Musa demonstrates the evil consequences of manipulation. On July 9, 2010, the 19-year-old was arrested by the police for attempting to assassinate the emir of Kano with a gun during a Jumal service at the Kano Central Mosque. The emir of Kano is one of the most prominent Muslim leaders in Nigeria. On interrogation, the almajiri confessed that he was only doing the bidding of his mallam, who also gave him the weapon and some charms. He added that a week earlier, he had deposited the sum of 1 million which he and his mallam had robbed from an Igbo trader (Abuh, 2010). Furthermore, confessions of children arrested in connection with $\mathrm{BH}$ terrorism provide insights into the vulnerability and radicalization that lead them into violence. Some of the 35 children released in May 2013 confessed to be almajirai. One of them admitted that they were paid about $\$ 30$ each by some politicians and rebel leaders to spy on troops, vandalize property, and maim and kill non-Muslims: "We were given a keg of petrol by our bosses to set some schools 
ablaze, which we did within Maiduguri and we were paid 5000 " (Alli, 2013, p. 4). Another almajiri "child soldier" said:

We were taken to Damaturu. We watched out for the soldiers at their units and reported back to them $[\mathrm{BH}]$. We were reporting when soldiers were at ease or enjoying themselves and when they were off guard, and we were paid for doing that (Alli, 2013, p. 4)

Conservative estimates put the number of people who have died in BH-related conflicts at over 3,600 (Osumah, 2013). Most of the victims are innocent civilians, including men, women and children, who have been killed in such public places as worship centers, schools, markets, and relaxation spots. A sizable number of security personnel have also been killed as a result of carefully planned and executed attacks on security formations such as police stations and soldier barracks. Media houses have also been bombed, as well as the U. N. office in Nigeria's federal capital territory, Abuja (LeVan, 2013). Apart from inflicting serious injuries and permanent disabilities on people, violent youth attacks in the caliphate North have also led to the internal displacement of thousands within Nigeria and a large flow of refugees into Niger, Chad, and Cameroon (Soria, 2012). But the Nigerian government and the Muslim community saw the almajiri menace coming. A former permanent secretary in the Ministries of Water Resources, Science and Technology, and Education in Jigawa state had in 2010 alerted the nation to the danger of the Quaranic students when he stated that "we are only grooming them as future terrorists not only in Nigeria, but in the whole of Africa" (Umenne, 2010, p. 6). Indeed, various studies have also implicated the almajiri system in several urban revolts in northern Nigeria (Agbiboa, 2013; Imobighe, 2012).

However, the use of social miscreants as canon fodder has a long history in northern Nigeria, as shown by the Maitatsine urban revolts which broke out in Kano in 1980 and spread to Maiduguri and Kaduna in 1982, Jimeta-Yola in 1984, and Gombe in 1985. Muhammed Marwa, who led the Maitatsine uprising which claimed over 5000 lives, obviously the precursor to $\mathrm{BH}$ terrorism, had exploited the dwindling economic situation of northern Nigeria in the early 1980 s by recruiting foot soldiers from the almajiri system (Loimeier, 2012; Winters, 1987). Street urchins who were unable to afford the basic necessities of life became diehard patriots of the Islamic sect and Marwa. The Maitatsines preached that killing was compulsory and they believed they would go to heaven if they killed arnas (infidels) (Elaigwu, 2005; Falola, 1998). 


\section{EXPLAINING ALMAJIRI-RELATED INSECURITY}

The almajiri menace, to reiterate, is a consequence of a terrible youth bulge syndrome. Apart from being the most populous country in Africa, Nigeria also has the highest birth rate on the continent (Aluaigba, 2009). High levels of illiteracy, unemployment, and poverty accompany this explosive youth demographic cohort in the North. As noted by theorists of youth bulge, such societies are prone to violent conflict.

One of the core drivers of violent conflicts in northern Nigeria is widespread illiteracy engendered by poor education. To date, the North has the highest level of illiteracy in the country despite efforts aimed at promoting literacy, including the universal primary education program launched in 1976 and the universal basic education (UBE) program, which was relaunched in 1999 (just before the proclamation of the millenium development goals by the international community). The UBE is aimed at providing free, universal basic education for every Nigerian child of school-going age. At best, these programs have only prioritized quantity over quality; as Hoechner remarks, "The push to expand primary school enrollment often has, for the children of the poor, resulted in swollen classes, lacking even the most basic educational resources, supervised sometimes by underpaid, barely trained teachers" (2011, p.719).

Though a national problem, educational crisis is worse in the North than in the South. The wide educational imbalance between the North-South divide has existed since colonial times when formal education was introduced into the country by European Christian missionaries. While the missionaries were given a free rein and allowed to establish schools in southern Nigeria, British administrators strictly restricited their activities in the northern region as part of a policy of indirect rule that allowed emirs there to remain in power as figureheads while in fact serving as agents of the British (Osaghae, 2002). As Mustapha (1986) notes, when Western education was finally introduced into the northern region, the system was aimed at training the sons of aristocrats and was used as a form of social control. The early exposure to Western education gave the southern region an edge over the North in administration and employment. Table 1 documents the educational imbalance between the regions prior to independence in 1960.

Instructively, table 1 shows that in 1957 (three years before Nigeria's independence) the northern region, which had over 16.8 million people (based on the 1952 census), had only 3,643 secondary school enrollments, whereas the southern region, with only 13.2 million, had 28,208 secondary school enrollments. The academic imbalance between the regions continued after independence, as shown in table 2 . 
Table 1. Difference in Modern Education between Northern and Southern Nigeria, 1906-1957

\begin{tabular}{|c|c|c|c|}
\hline \multicolumn{2}{|c|}{$\begin{array}{c}\text { Southern Nigeria (Population } 13.2 \text { Million } \\
\text { according to } 1952 \text { Census) }\end{array}$} & \multicolumn{2}{|c|}{$\begin{array}{l}\text { Northern Nigeria (Population } 16.8 \text { Million } \\
\text { according to } 1952 \text { Census) }\end{array}$} \\
\hline \multicolumn{2}{|c|}{ Student Enrollment } & \multicolumn{2}{|c|}{ Student Enrollment } \\
\hline Primary & Secondary & Primary & Secondary \\
\hline 11,872 & 20 & Not available & 0 \\
\hline 138,249 & 518 & 5,210 & 0 \\
\hline 538,391 & 9,657 & 70,962 & 251 \\
\hline $1957 \quad 2,343,317$ & 28,208 & 185,484 & 3,643 \\
\hline
\end{tabular}

Source: Anifowose (2006, p. 46).

Table 2. Primary Enrollment Fractions, 1970

\begin{tabular}{l|c}
\hline \multicolumn{1}{c|}{ State } & Percentage of Children Enrolled in Primary School \\
\hline Northern states & 28.2 \\
\hline Kwara & 18.0 \\
\hline Benue-Plateau & 10.5 \\
\hline North-Central & 8.6 \\
\hline Northeast (including present-day Borno) & 4.9 \\
\hline Northwest (including present-day) Sokoto & 4.4 \\
\hline Kano & \\
\hline Southern states & 87.2 \\
\hline Lagos & 74.0 \\
\hline Midwest & 64.1 \\
\hline East-Central & 46.3 \\
\hline Southeast & 45.6 \\
\hline West & 34.5 \\
\hline Rivers & \\
\hline
\end{tabular}

Source: Nduka (2006, p. 197).

Today, the northern region remains backward in terms of formal education and human capital development. In fact, in its latest education-for-all global monitoring report, UNESCO reveals that 10.5 million school-age children are out of school in Nigeria, accounting for about 47 percent of the 12 nations sampled. The report shows 
that one out of 5 school-age child is out of school in the country. Other countries sampled included Pakistan (1.5 million), Ethiopia (2.4 million), India (2.3 million), Philippines (1.5 million) Cote d'Ivoire (1.2 million), Burkina Faso (1 million), Niger (1 million), Kenya (1 million), Yemen (0.9 million), Mail (0.8 million), and South Africa (0.7 million) (Guardian, 2013b).

The statistics of a recent educational survey are even more appalling. The report shows that only 28 percent of sampled school-age children attend school in Zamfara, 29 percent in Borno, 29 percent in Kebbi, 34 percent in Sokoto, and 42 percent in Yobe. The survey also shows that 72 percent of children in Borno have never been to school. By contrast, the report shows that over 90 percent of children sampled in the southern region were in school (Nation, 2011). Even a few well-intended educational programs of the government have not been popular with the people in the northern region. For example, to check the growing linkage between the almajiri cohort and $\mathrm{BH}$, the federal government created the Ministerial Committee on Madrasah Education on February 16, 2010. The report of the committee resulted in the setting up of an almajiri education program, which was aimed at integrating the million-plus almajirai into the UBE program. As part of the almajiri education program, 89 model almajiri schools with state of the art equipment, including boarding facilities, were to be built in 25 states across the country (see table 3). Expectedly, the almajirai populated and $\mathrm{BH}$-prone states of Kano, Borno, and Bauchi were projected to have 7, 6 and 5 model schools respectively.

Table 3. Number of Model Almajiri Schools Proposed, by State

\begin{tabular}{c|l|l|l|l}
\hline \multirow{2}{*}{ S/No. } & \multirow{2}{*}{ State } & \multicolumn{2}{|c|}{ Model } & \multirow{2}{*}{ Total } \\
\cline { 3 - 5 } & & & 1 & 4 \\
\hline 1 & Adamawa & 3 & 2 & 5 \\
\hline 2 & Bauchi & 3 & 1 & 6 \\
\hline 3 & Borno & 5 & 0 & 1 \\
\hline 4 & Edo & 1 & 0 & 1 \\
\hline 5 & Ekiti & 1 & 1 & 2 \\
\hline 6 & Gombe & 1 & 1 & 4 \\
\hline 7 & Jigawa & 3 & 1 & 5 \\
\hline 8 & Kaduna & 4 & 1 & 4 \\
\hline 9 & Kano & 6 & 1 & 4 \\
\hline 10 & Katsina & 3 & &
\end{tabular}




\begin{tabular}{|c|c|c|c|c|}
\hline S/No. & State & \multicolumn{2}{|c|}{ Model } & Tota \\
\hline 11 & Kebbi & 2 & 1 & 3 \\
\hline 12 & Kogi & 4 & 0 & 4 \\
\hline 13 & Kwara & 4 & 0 & 4 \\
\hline 14 & Lagos & 1 & 0 & 1 \\
\hline 15 & Nasarawa & 3 & 2 & 5 \\
\hline 16 & Niger & 3 & 2 & 5 \\
\hline 17 & Ogun & 2 & 0 & 2 \\
\hline 18 & Ondo & 1 & 0 & 1 \\
\hline 19 & Osun & 2 & 0 & 2 \\
\hline 20 & Oyo & 4 & 0 & 4 \\
\hline 21 & Rivers & 0 & 1 & 1 \\
\hline 22 & Sokoto & 4 & 1 & 5 \\
\hline 23 & Taraba & 2 & 0 & 2 \\
\hline 24 & Yobe & 3 & 1 & 4 \\
\hline 25 & Zamfara & 6 & 1 & 7 \\
\hline \multicolumn{2}{|c|}{ Total } & 71 & 18 & 89 \\
\hline
\end{tabular}

Source: Adapted by authors from almajiri model school committee report.

The first almajiri model school built at Gagi village in Sokoto was commissioned in 2012. Ironically, despite the fact that tuition and accommodation are free and the pupils are not charged for their meals, many Muslim parents have refused to send their children to the school for fear of their children being corrupted by Western education. Such an attitude creates an ignorant pool of vulnerable youths who can be easily manipulated by conflict entrepreneurs. While the government may not have sensitized the people adequately to accept the new educational policy for the almajirai, such public disdain for formal education is not only historical but also resonates in $\mathrm{BH}$ narratives of grievance. In fact, the phrase "boko haram" literally means "Western education is forbidden" in the Hausa language (Aghedo \& Osumah, 2012).

Another intervening variable that makes the almajiri demographic cohort volatile is the high level of unemployment in the North. As noted earlier, the BH became the second deadliest terrorist group in the world in 2012 ostensibly because of the cheap availability of almajiri foot soldiers that are willing to put their destinies in the hands 
of the BH. Indeed, as Urdal (2006) argues, when a large pool of young people find themselves confronting unemployment, poverty, and squalor that lead to unmitigated despondency, they are increasingly likely to join a rebellion as an alternative way of generating income. It is worse for individuals like the almajirai who are uneducated and therefore lack the hope and income-earning opportunities that come with education (Collier, 2000). Nigeria is a nation that places a high premium on paper qualifications at the expense of experience in the labor market. As a result, people such as the almajirai who lack generally acceptable certificates stand little chance of employment. As shown in able 4, the rate of unemployment in northern Nigeria is much higher than in the South. Interestingly, even within the region, the rate of unemployment in $\mathrm{BH}$ hotbed states in 2011 is relatively high: 41 percent in Bauchi, 35.6 perccent in Yobe, and 29 percent in Borno.

Table 4. Unemployment Rates, by State, 2007-2011

\begin{tabular}{l|r|r|r|r|l}
\hline \multicolumn{1}{c|}{ State } & 2007 & 2008 & 2009 & 2010 & 2011 \\
\hline Abia & 25.1 & 11.9 & 14.5 & 22.8 & 11.2 \\
\hline Adamawa & 21.5 & 13.5 & 29.4 & 24.6 & 33.8 \\
\hline Akwa-lbom & 18.0 & 11.1 & 34.1 & 27.7 & 18.4 \\
\hline Anambra & 14.9 & 7.3 & 16.8 & 10.8 & 12.2 \\
\hline Bauchi & 20.5 & 6.9 & 37.2 & 27 & 41.4 \\
\hline Bayelsa & 21.9 & 67.4 & 41.5 & 27.4 & 23.9 \\
\hline Benue & 7.9 & 7.8 & 8.5 & 6 & 14.2 \\
\hline Borno & 12.5 & 11.8 & 27.7 & 26.7 & 29.1 \\
\hline Cross River & 32.8 & 18.9 & 14.3 & 27.9 & 18.2 \\
\hline Delta & 22.9 & 11.5 & 18.4 & 27.9 & 27.2 \\
\hline Ebonyi & 7.9 & 5.1 & 12 & 25.1 & 23.1 \\
\hline Edo & 14.8 & 15.6 & 12.2 & 27.9 & 35.2 \\
\hline Ekiti & 11.4 & 11.5 & 20.6 & 28 & 12.1 \\
\hline Enugu & 14.1 & 10.5 & 14.9 & 28 & 25.2 \\
\hline Gombe & 16.9 & 7.6 & 32.1 & 27.2 & 38.7 \\
\hline Imo & 28.3 & 17.4 & 20.8 & 28.1 & 26.1 \\
\hline Jigawa & 27.0 & 5.9 & 26.5 & 14.3 & 35.9 \\
\hline Kaduna & 8.7 & 12.7 & 11.6 & 12.4 & 30.3 \\
\hline
\end{tabular}




\begin{tabular}{l|c|c|c|c|c}
\hline \multicolumn{1}{c|}{ State } & 2007 & 2008 & 2009 & 2010 & 2011 \\
\hline Kano & 10.1 & 5.8 & 27.6 & 14.7 & 21.3 \\
\hline Katsina & 10.9 & 11.8 & 37.3 & 11 & 28.1 \\
\hline Kebbi & 1.3 & 16.5 & 12 & 10.7 & 25.3 \\
\hline Kogi & 14.6 & 16.4 & 19 & 9.5 & 14.4 \\
\hline Kwara & 17.7 & 10.2 & 11 & 2.7 & 7.1 \\
\hline Lagos & 13.7 & 7.6 & 19.5 & 27.6 & 8.3 \\
\hline Nasarawa & 11.8 & 17 & 10.1 & 3.4 & 36.5 \\
\hline Niger & 4.2 & 3.9 & 28 & 11.7 & 39.4 \\
\hline Ogun & 3.6 & 5.8 & 8.5 & 27.8 & 22.9 \\
\hline Ondo & 6.7 & 6.3 & 14.9 & 28 & 12.5 \\
\hline Osun & 7.2 & 6.5 & 12.6 & 27.6 & 3 \\
\hline Oyo & 8.1 & 8.7 & 14.9 & 27.7 & 8.9 \\
\hline Plateau & 6.8 & 4.7 & 7.1 & 10.4 & 25.3 \\
\hline Rivers & 66.4 & 12.1 & 27.9 & 27.8 & 25.5 \\
\hline Sokoto & 12.3 & 5.9 & 22.4 & 15.9 & 17.9 \\
\hline Taraba & 15.2 & 19.9 & 26.8 & 24.7 & 12.7 \\
\hline Yobe & 24.4 & 12.8 & 27.3 & 26.2 & 35.6 \\
\hline Zamfara & 19.1 & 16.4 & 13.3 & 14.5 & 42.6 \\
\hline FCT & 47.8 & 8.7 & 21.5 & 11.8 & 21.1 \\
\hline Nigeria (national) & 12.7 & 14.9 & 19.7 & 21.4 & 23.9 \\
\hline Soure: Nigen & & & & \\
\hline
\end{tabular}

Source: Nigeria, National Bureau of Statistics (2012, p. 41).

A number of scholars have noted that the combination of a massive youth population and a high rate of unemployment is a recipe for political instability, rebellion, and warfare (Collier, 2007; Urdal, 2007). Indeed, unemployed northern youth bear a strong animosity toward educated young people from the South, whom they accuse of being too sophisticated and domineering in the labor market. A similar hatred for prospective employees also allegedly fuels $\mathrm{BH}$ attacks on tertiary institutions in the northern region. In Mamudo in July 2013, BH killed 31 students, a teacher, and one local resident. In June 2013, the group launched an attack on the government secondary school in Damaturu, killing seven students and two teachers; and the bombing of a Christian worship center at Bayero University, Kano in April 2012, killed two professors and 13 others (Egharevba \& Aghedo, 2013; Mgboh, 2012). 
Relative poverty is another intervening variable driving the correlation between the almajiri population and insecurity in the region. The level of poverty in northern Nigeria is higher than the national average. And the worst hit people are the almajirai, who are totally dependent on alms for survival. Owing to widepread poverty, some parents are left with no choice than to continue sending their children into the street disguised as alimajirai . According to the National Bureau of Statistics 2010 poverty profile, though poverty permeates the entire country, it is more profound in the North. The report shows that among the six geopolitical zones of the country, the Northwest and Northeast (operational bases of $\mathrm{BH}$ ) recorded the highest poverty rates of 70 percent and 69 percent, respectively. The projection of the bureau for year 2011 was also gloomy with predictions of 71.5 percent, 61.9 percent, and 62.8 percent poverty rates for North-Central, Northeast and Northwest, respectively (Punch, May 8, 2012). The U.N. 2008-2009 human development report rated the North as the poorest region of the country, using such indicators as child mortality, maternal mortality, and the presence or absence of diseases like polio and measles, which have been nearly eradicated in southern Nigeria (Agbaegbu, 2012).

Furthermore, the proliferation of gangs, militias, and vigilantes, many of which operate outside state control, leads to insecurity by providing a source of weapons and training for miscreants, including almajirai. The apparent weakness of the Nigerian security establishment, particularly the police force, which is saddled with the responsibility of maintaining internal security, has encouraged the activities of alternative providers of security such as self-help vigilante groups (Hills, 2011). In the Southwest of Nigeria, the O'odua People's Congress militant youth wing engages in some form of policing; in the Southeast, the Bakassi Boys (now officially disbanded) took to vigilantism in the region; and in northern Nigeria, the Yan Daba participates in what Conerly (2007) describes as "policing by force." A common thread that runs in these groups is that the method employed in fulfilling their mandate (ensuring that their domian is secured internally and externally) is force, which increases the scope of violence and criminality.

In much of northern Nigeria, the Yan Daba (a reserved army of the unemployed) often take care of the almajirai, who serve as the main pool for Yan Daba recruitment. The almajirai play the role of errand boys while the Yan Daba membership act as mentors, whom the average almajiri child looks up to. This relationship is cemented by the seeming unity of purpose that they share: standing in antithesis to anything or anybody perceived as responsible for their dehumanized condition. These groups often act in ways that are indicative of the ease with which they metamorphose into tribal and religious terrorists. The Yan Daba sometimes forments trouble in the North in reaction to events that occur even outside the region. In 1999, for example, when 
Hausa residents clashed with their Yoruba hosts in the town of Sagamu in Ogun state, it was the Yan Daba group that organized a reprisal attack against the Yoruba residents in Kano. The Hausa residents of Kano are known to have great trust in the ability of the Yan Daba to protect them, to the extent of boasting arrogantly of the group's capacity to annihilate other militant groups in the South if they get the "white flag" from the state government. This suggests some form of collaboration between the group and the state. Human Rights Watch (2005) ascribes the huge success of the 2004 religious attacks in Kano (home to the highest number of destitute children) to the involvement of the almajirai. Also, the postelection violence in 2011, which claimed the lives of over 800 Nigerians, was said to have been prosecuted by teenagers who attend Quranic schools (Elombah, 2011).

Groups like the Yan Daba, BH, and their almajiri recruits claim to be committed to the purification of Islam, which sets them against anybody that fails to adhere to the dictates of the Quran, and this includes even Muslims of Yoruba extraction, who they regard as untrue Muslims for sabotaging their desire for an orthodox Islam, along with the Nigerian police force, which attempts to curtail their activities. Recent threats and attacks on police headquarters and other police posts by the BH sect make clear just how antagonistic the relationship between the $\mathrm{BH}$ and the police is (Adisa, 2011; Human Rights Watch, 2011) and is also indicative of the BH's willingness to exterminate any opposition to its so-called Islamization agenda. Yet, religion is only used as a tool to legitimize their violent operations, which are carried out by the spiraling youth population that has become uncontrollable due to the region's development crises.

By and large, the crisis of governance is a critical driver of insecurity in the northern region. It explains why the number of youths far exceeds the number of available jobs, why illiteracy is prevalent, and why poverty remains pervasive across the country, despite the fact that Nigeria is Africa's largest oil-producing nation and second largest economy. Nigeria's ruling elite are insensitive to the plight of the people, in gross contravention of section 16(2) (d) of chapter 2 of the country's 1999 Constitution, which enjoins the state to direct its policy toward ensuring that suitable and adequate shelter and food are provided for the people, that a reasonable national minimum living wage, including old age care and pensions, are guaranteed for workers, and that unemployment and sick benefits are provided for all, as well as ensuring the welfare of the disabled. Despite Nigeria's enormous oil and gas resouces, the country paradoxically remains a "rich country with poor people" owing to monumental leadership corruption. Obscene corruption has colossally damaged the image of Nigeria locally and internationally, as evidenced by the country's persistent poor rating in the Corruption Perception Index (see table 5). 
Table 5. Transparency International's Corruption Perception Index (CPI) for Nigeria 1996-2010

\begin{tabular}{c|c|c|c|c|c}
\hline S/No. & & $\begin{array}{c}\text { CPI Score } \\
(\text { Max=10 })\end{array}$ & Ranking & $\begin{array}{c}\text { Number of Countries } \\
\text { Ranked }\end{array}$ & $\begin{array}{c}\text { Number of Countries } \\
\text { Ranking Worse }\end{array}$ \\
\hline 1 & 1996 & 0.69 & 54 & 54 & 0 \\
\hline 2 & 1997 & 1.76 & 52 & 52 & 0 \\
\hline 3 & 1998 & 1.9 & 81 & 85 & 1 \\
\hline 4 & 1999 & 1.6 & 98 & 99 & 0 \\
\hline 5 & 2000 & 1.2 & 90 & 90 & 1 \\
\hline 6 & 2001 & 1.0 & 90 & 91 & 1 \\
\hline 7 & 2002 & 1.6 & 101 & 102 & 5 \\
\hline 8 & 2003 & 1.4 & 132 & 133 & 13 \\
\hline 9 & 2004 & 1.6 & 144 & 146 & 31 \\
\hline 10 & 2005 & 1.9 & 152 & 159 & 59 \\
\hline 11 & 2006 & 2.2 & 142 & 163 & 50 \\
\hline 12 & 2007 & 2.2 & 147 & 179 & 44 \\
\hline 13 & 2008 & 2.7 & 121 & 180 & 180 \\
\hline 14 & 2009 & 2.5 & 130 & 178 & 13 \\
\hline 15 & 2010 & 2.4 & 134 & & 13 \\
\hline
\end{tabular}

Source: Francis, Deirdre, \& Rossiasco (2011, p. 44).

Thus, it would appear from table 5 that Nigeria's rating only improved a little when the ranking involved more corrupt states (e.g., in 2008 and 2009), an indication that did not show much progress as further revealed by the appalling CPI score.

As noted by Akingbade and Akinola (2013, p. 4), the immediate cause of the BH uprising is traceable to poor governance, corruption, and the manipulation of deprived youth by many politicians "who were looking for votes and allies in religious terror machines and made pledges of establishing institutions based on Islam." Instructively, these conflicts further compound the development crisis in the Muslim-dominated region. The human and economic costs of the insurgency are enormous, but there are also other less visible negative consequences. For example, no investor would want to invest in areas that are not stable or prone to violent conflicts. In fact, the wave of insecurity has forced many businesses to close down and others to relocate to safer areas (Aghedo \& Osumah, 2012). This exacerbates the employment, poverty, and education crises. For example, incessant attacks on schools in Yobe and Borno in 2013 not only led to the destruction of buildings and instructional materials but also to the closing 
down of all schools for several months owing to safety concerns (Egharevba \& Aghedo, 2013). This is a huge setback for a region that is already educationally backward.

\section{CONCLUSION: TAMING THE MONSTER}

The article has argued that violent insecurity in northern Nigeria is driven by the phenomenon of youth bulge. The region is home to an unusually large army of itinerant Quranic pupils who operate on the margins of society. The destitute almajirai depend largely on public philanthropy and alms for survival—a fact that makes them vulnerable to conflict mobilization. However, we have contended that the presence of a large pool of street urchins does not cause conflict in itself, that some crucial variables intervene to precipitate violence. We have presented a graphic description of the socioeconomic deprivations and lack that characterizes the sprawling environment the almajirai inhabit. Without their receiving the socially required educational training, the labor market is shut against the street urchins. The resultant unemployment drives the beggars into dependency and abject poverty. The vulnerability arising from this destitution makes the almajirai easy prey to conflict entrepreneurs, religious bigots and $\mathrm{BH}$ insurgents. Thus, violent insecurity in northern Nigeria is fuelled by the explosive population of youth who lack sustainable livelihoods. Notwithstanding the popular rhetoric of Islamic jihadism, the solution to the conflict lies more in development building and state intervention.

To mitigate widespread insecurity in the sprawling north, effective and quality education is necessary. Since there is a deep-seated disdain for Western education in the region, the almajiri education system should be overhauled, and orthodox subjects such as mathematics and English should be added to the curriculum together with relevant business and technical subjects. The state-owned National Business and Technical Examinations Board (NABTEB) can be made to assume this responsibility because it already conducts national examinations in these subjects. The mallams and other experts should be used in teaching these vocational courses. The inclusion of the mallams, whom the almajirai and their parents are already used to, will make the families receptive. However, the Islamic scholars will have to go through the necessary retraining for curricular and pedagogic reasons. It is crucial that this integration of modern education into the almajiri school system be preceded and followed through by public sensitization campaigns, preferably in local languages and involving mallams, Muslim clerics, and local community leaders. All these will ensure that the policy does not suffer the same fate as the almajiri model education program.

Considering the premium on certificates in Nigerian society, it is important that 
graduates of the new system be given certificates by NABTEB after they have satisfied the requirements set out by the reform. The issuance of certificates will enable the graduates to get employment in government and private sectors, thereby reducing poverty and reliance on alms, which make the youth vulnerable. Also, the monthly revenues allocation to all states in the federation, including those in the North, should be monitored by citizens and civil society groups to ensure that such revenues are put to good use. As noted, almajiri-related insecurity is fallout from the governance crisis, especially the privatization of public resources by the ruling elite that has led to poor education, unemployment, and mass poverty. Though corruption is prevalent in all sectors and areas of Nigeria, it is worse in the northern region. Therefore, civil society groups and enlightened individuals everywhere in the country should scrutinize revenue allocation to the North to reduce diversion. But for pervasive corruption, the North should not be underdeveloped since its political elite have dominated Nigerian leadership more than their counterparts in the South. Obviously, oil revenue allocations to the region have been largely mismanaged.

Furthermore, since many arrested almajiri members of BH have confessed to being sponsored, the government should muster the required political will and bring sponsors of violence to book. Religious clerics who preach hatred and intolerance should be monitored and cautioned. If they persist in inciting the youth against the state and society, they should be tried openly and fairly in the courts and appropriate punishment meted out to them. This will serve as deterrence to others and so check the culture of impunity among conflict entrepreneurs. Lastly, the government needs to ensure that the Nigerian business environment is conducive for investment. Apart from pervasive insecurity, Nigeria suffers from abysmal infrastructural decay. For example, the electric power supply is epileptic. And a weak infrastructure serves as a disincentive to investors because it increases the cost of doing business in a country. Thus, when the government at all levels provides the necessary infrastructure and ensures an appreciable degree of political stability, investors will be attracted into the country, including the northern region. This will boost youth employment and alleviate poverty and ultimately increase the opportunity costs of rebellion.

\section{REFERENCES}

Abdullah, I. 1998. Bush path to destruction: The origin and character of the revolutionary United Front/Sierra Leone. Journal of Modern African Studies, 36, (2): 203-235.

Abuh, A. 2010. Foiled: An Almajiri's plot to kill emir. Guardian, July 15.

Adisa, T. 2011. FBI, SSS unravel secret of Boko Haram's blasts. Sunday Tribune, 
July 17.

Adofetekun, A. 2011. Teenager hangs self. Daily Sun, August 25.

Agbaegbu, T. 2012. Poverty: The rampaging scourge in the north. Newswatch, April 7.

Agbiboa, D. E. 2013. No retreat, no surrender: Understanding the religious terrorism of Boko Haram in Nigeria. African Study Monographs, 34 (2): 65-84.

Aghedo, I. 2013. Winning the war, losing the peace: Amnesty and the challenges of post-conflict peace-building in the Niger Delta, Nigeria. Journal of Asian and African Studies, 48 (3): 256-278.

Aghedo, I., \& Osumah, O. 2012. The Boko Haram uprising: How should Nigeria respond? Third World Quarterly, 33 (5): 853-869.

Akingbade, T., \& Akinola T. 2013. How Almajiri system, climate change fuel terrorism, religious crisis. Guardian, June 16.

Alao, A. 2013. Islamic radicalization and violent extremism in Nigeria. Conflict, Security and Development, 13 (2):127-147.

Alli, Y. 2013. We were paid 5000 to burn schools—freed Boko Haram kids. Nation, June 1.

Aluaigba, M. T. 2009. Circumventing or superimposing poverty on the African child? The Almajiri syndrome in northern Nigeria. Childhood in Africa, 1 (1): 19-24.

Anifowose, R. 2006. Violence and politics in Nigeria: The Tiv and Yoruba experience. 2nd ed. Lagos: First Academic Publishers.

Awofeso, N., Ritchie, J., \& Degeling, P. 2003. The Almajiri heritage and the threat of non-state terrorism in northern Nigeria: Lessons from Central Asia and Pakistan. Studies in Conflict and Terrorism, 26 (4): 311-325.

Bricker, N. Q, \& Foley, M. C. 2013. The effect of youth demographics on violence: The importance of the labour market. International Journal of Conflict and Violence, 7 (1): 1-15.

Campbell, J. 2013. The United States designates Boko Haram and Ansaru as foreign terrorist organizations. Council on Foreign Relations, November 14. http://blogs. cfr.org/campbell/2013/11/14/the-united-states-designates-boko-haram-and -ansaru-as-foreign-terrorist-organizations.

Chabal, P. 2005. Introduction-violence, power and rationality: A political analysis of conflict in contemporary Africa. In P. Chabal, U. Engel, \& A.-M. Gentili (eds.), Is violence inevitable in Africa? Theories of conflict and approaches to conflict resolution (pp. 1-17). The Netherlands: Koninklijke Brill.

Christiansen, C., Utas, M., \& Vigh, H. E. 2006. Introduction: Navigating youth, generating adulthood. In C. Christiansen, M. Utas, \& H. E. Vigh (eds.). Navigating youth, generating adulthood: Social becoming in an African context (pp. 9-28). Uppsala: Nordiska Afrikainstitutet. 
Collier, P. 2000. Doing well out of war: An economic perspective. In M. Berdal \& D. M. Malone (eds.), Greed and grievance: Economic agendas in civil wars (pp. 91-111). Boulder: Lynne Rienner.

Collier, P. 2007. The bottom billion: Why the poorest countries are failing and what can be done about it. Oxford: Oxford University Press.

Conerly, C. 2007. "Policing" through violence: Fear, vigilantism, and the politics of Islam in northern Nigeria. In D. Pratten \& Atryee Sen (eds.), Global vigilantes (pp. 93-124). London: Hurst.

Corner House. 2004. Angry young men, veiled young women: Constructing a new population threat. Corner House briefing paper 34, December 2. http://www. thecornerhouse.org.uk/resource/angry-young-men-veiled-young-women.

Dawha, E. M. K. 1999. Yan Daba, Yan Banga and Yan Daukar Amarya: A study of criminal gangs in northern Nigeria. Ibadan: IFRA/African Book Builders.

Egharevba, J., \& Aghedo, I. 2013. Promoting unity in diversity: The imperative of social transformation for managing the Boko Haram uprising in Nigeria. Nigerian Journal of Social Studies, XVI (1): 111-129.

Elaigwu, A. V. 2005. The military and management of religious violence in Nigeria: The Maitatsine crisis in Jimeta-Yola, 1984. In A. M. Yakubu, R. T. Adegboye, C. N. Ubah, \& B. Dogo (eds.), Crisis and conflict management in Nigeria since 1980, vol. 2 (pp.741-752). Kaduna: Nigerian Defence Academy.

Elombah, D. 2011. The turbulent north and the Almajiri threat. Pt. 1. Elombah.com, May 13. www.elombah.com/index.php?option=com_content\&view=article\&id $=6541$ :nigeria-the-turbulent-north-and-the-almajiri-threat-part-1\&catid=52:daniel -elombah\&Itemid=73.

Falola, T. 1998. Violence in Nigeria: The crisis of religious politics and secular ideologies. Rochester: University of Rochester Press.

Foley, F, 2009. Reforming counterterrorism: Institutions and organizational routines in Britain and France. Security Studies, 18 (3): 435-478.

Francis, P., LaPin, D., \& Rossiasco, P. 2011. Securing development and peace in the Niger Delta: A social and conflict analysis for change. Washington, DC: Woodrow Wilson International Center for Scholars.

Goldstone, J. A. 2002. Population and security: How demographic change can lead to violent conflict. Journal of International Affairs, 56 (1): 3-21.

Gore, C., \& Pratten, D. 2003. The politics of plunder: The rhetorics of order and disorder in southern Nigeria. African Affairs, 102 (407): 221-240.

Guardian. 2013a. Boko Haram ranks second on global terror list. June 11.

Guardian. 2013b. Poor school enrollment and Nigeria's future. June 25.

Hart, D., Atkins, R., Markey, P., and Youniss, J. 2004. Youth bulges in communities: 
The effects of age structure on adolescent civic knowledge and civic participation. Psychological Science, 15 (9): 591-597.

Hilker, L. M., and Traser, E. 2009. Youth exclusion, violence, conflict and fragile states: A report prepared for DFID's equity and rights team. Social Development Direct, April 30.

Hills, A. 2011. Policing a plurality of worlds: The Nigerian metropolitan Kano. African Affairs, 111 (442): 46-66.

Hoechner, H. 2011. Striving for knowledge and dignity: How Quranic students in Kano, Nigeria, learn to live with rejection and educational disadvantage. European Journal of Development Research, 23 (5): 712-728.

Hoffman M., \& Jamal, A. 2012. The youth and the Arab Spring: Cohort differences and similarities. Middle East Law and Governance, 4 (1): 168-188.

Human Rights Watch. 2005. Revenge in the name of religion: The cycle of violence in Plateau and Kano States. Human Rights Watch Reports, 17 (8A), May 26. www.hrw.org/en/news/2008/12/03/nigeria-protect-anticorruption-czar.

Human Rights Watch. 2011. Nigeria: Boko Haram attacks indefensible. Human Rights Watch, November 9. www.hrw.org/nwes/2011/11/08/nigeria-boko-haram-attacks -the-indefensible.

Huntington, S. P. 1996. The clash of civilizations and the remaking of world order. London: Free Press.

Imobighe, T.A. 2012. Governance and Nigeria's national security. In T. A. Imobighe and S. I. Ebohon (eds.), Themes and issues on Nigerian governance and politics (pp.241-263). Kuru: National Institute Press.

Kaplan, D. R. 1994. The coming anarchy. Atlantic Monthly, 273 (2): 44-76.

Kaplan, D. R. 2006. The coming anarchy. In G. O Tuathail, S. Dalby, \& P. Routledge (eds.), The geopolitics reader (pp.188-195). 2nd ed. London: Routledge

Kegley, C. W., \& Blanton, S. L. 2011. World politics: Trend and transformation, 20102011. 11th ed. Melbourne, Australia: Wadsworth.

Kew, D., \& Lewis, P. 2013. Nigeria. In M. Kesselman, J. Krieger, \& W. A. Joseph (eds.), Introduction to comparative politics: Political challenges and changing agendas (pp. 522-575). 6th ed. Belmont, CA: Wadsworth.

LaGraffe, D. 2012. The youth bulge in Egypt: An intersection of demographics security and the Arab Spring. Journal of Strategic Security, 5 (2): 65-80.

Last, M. 2008. The search for security in Muslim northern Nigeria. Perspectives on vigilantism in Nigeria, Africa, 78 (1): 41-63.

LeVan, A. C. 2013. Sectarian rebellions in post-transition Nigeria compared. Journal of Intervention and Statebuilding, 7 (3): 335-352.

Lewis, M. P. 2004. Getting the politics right: Governance and economic failure in 
Nigeria. In R. I. Rotberg (ed.), Crafting the new Nigeria: Confronting the challenges (pp.99-124). Boulder, CO: Lynne Rienner.

Loimeier, R. 2012. Boko Haram: The development of a militant religious movement in Nigeria. African Spectrum, 47 (2-3): 137-155.

Maclay, C., \& Özerdem, A. 2010. "Use" them or "lose" them: Engaging Liberia's disconnected youth through socio-political integration. International Peacekeeping, 17 (3): 343-360.

Mgboh, D. 2012. Two professors, 13 others killed. Daily Sun, April 30.

Mkandawire, T. 2002. The terrible toll of post-colonial rebel movements in Africa: Towards an explanation of the violence against the peasantry. Journal of Modern Africa Studies, 40 (2): 181-215.

Moller, H. 1968. Youth as a force in the modern world. Comparative Studies in Sociology and History, 10 (3): 238-260.

Momoh, A. 2000. Youth culture and area boys in Lagos. In A. Jega (ed.), Identity transformation and identity politics under structural adjustment in Nigeria (pp.181-203). Uppsala: Nordiska Afrikainstitutet.

Mustapha, A.R. 1986. The national question and radical politics in Nigeria. Review of Africa Political Economy, 13 (37): 81-86.

Nation. 2011. North still backward in education. August 25.

Nduka, O. 2006. The roots of African underdevelopment and other essays. Ibadan: Spectrum.

Nigeria, National Bureau of Statistics. 2012. Social statistics in Nigeria. Abuja: National Bureau of Statistics.

O'Brien, D. B. C. 1996. A lost generation? Youth, identity and state decay in West Africa. In R. P. Werbner and T. Ranger (eds.), Postcolonial identities in Africa (pp.55-74). London: Zed Books.

Oladipo, A. 2012. The Almajiri syndrome: Searching for lasting solutions. Nigerian Tribune, April 20. www.tribune.com.ng/index.php.politics/39561-the-almajiri -syndrome-searching-for-lasting-solutions.

Oladosu, A. G. A. S. 2012. Arabic and Islamic education in Nigeria: The case of AlMajiri schools. World Academy of Science, Engineering and Technology, 71: 1820-1824.

Olagunju, L. 2012. Almajirai, street kids and a nation's future. Nigerian Tribune, April 19. www.tribune.com.ng/index.php/the-friday-edition/39559-almajirai-street-kids -and-a-nations-future.

Olley, B. O. 2006. Social and health behaviors in youth of the streets of Ibadan, Nigeria. Child Abuse and Neglect, 30 (3): 271-282.

Osaghae, E. E. 2002. Crippled giant: Nigeria since independence. Ibadan: John 
Archers.

Osaghae E. E. 2007. Fragile states. Development in Practice, 17 (4): 691-699.

Osumah, O. 2013. Boko Haram insurgency in northern Nigeria and the vicious cycle of internal insecurity. Small Wars and Insurgencies, 24 (3): 536-561.

Punch. 2012. Editorial: Car gifts for traditional rulers. May 8.

Richard, W. 2006. Rebellious youth in colonial Africa. Journal of Africa History, 47 (1): 77-92.

Schomaker, R. 2013. Youth bulges, poor institutional quality and missing migration opportunities-triggers of and potential counter-measures for terrorism in MENA. Topics in Middle Eastern and African Economics, 15 (1): 116-140.

Soria, V. 2012. Global jihad sustained through Africa: A report by the UK terrorism analysis. UKTA, 2, April 4. http://www.rusi.org/analysis/commentary/ref:C4F7 BDEE390DBB/\#.UrckMWRDtsg.

Ukiwo, U. 2002. Deus ex machina or Frankenstein monster? The changing roles of Bakassi Boys in eastern Nigeria. Democracy and Development: Journal of West African Studies, 3 (1): 39-51.

Umenne, C.-N. 2010. We are grooming Almajirai as future terrorists if we don't control them now. Guardian, April 24.

Urdal, H. 2006. A clash of generations? Youth bulges and political violence. International Studies Quarterly, 50 (3): 607-629.

Vigh, E. H. 2006. Social death and violent life chances. In C. Christiansen, M. Utas and H. E. Vigh (eds.), Navigating youth, generating adulthood: Social becoming in an African context (pp. 31-60). Uppsala: Nordiska Afrikainstitutet.

Winters, A. C. 1987. Koranic education and militant Islam in Nigeria. International Review of Education, 32 (1): 171-185 